\title{
Computational Study of Geometry, Polarizability, Hyperpolarizability and Molecular Docking Studies of Naproxen
}

\section{Sharmin Aktar ${ }^{1}$, Mohammad Firoz Khan ${ }^{1}$, Muhammed Mahfuzur Rahman ${ }^{1}$ and Mohammad A. Rashid ${ }^{2}$}

\author{
${ }^{1}$ Computational Laboratory, Department of Pharmacy, State University of Bangladesh, \\ Dhaka- 1205, Bangladesh \\ ${ }^{2}$ Department of Pharmaceutical Chemistry, University of Dhaka, Dhaka- 1000, Bangladesh
}

Received: May 22, 2016; Accepted: June 02, 2016; Published (web): June 20, 2016

\begin{abstract}
A computational assessment of geometry, molecular electrostatic potential (MESP), Mulliken charge distribution, polarizability, hyperpolarizability and molecular docking study of naproxen with human COX-2 enzyme were conducted. B3LYP level of theory using $6-31 \mathrm{G}(\mathrm{d}, \mathrm{p})$ basis set was used to optimize the structure of naproxen. The default Polarizable Continuum Model (PCM) of Gaussian09 software was applied for all calculations involving solvents, water and $n$-octanol. Almost all bond lengths and angles of naproxen agree very well with the X-ray crystal structure suggesting that the molecule is well described with B3LYP/6-31G(d,p) level of theory. The polarizability and first order hyperpolarizability were increased with the increase of solvent polarity. Moreover, docking study revealed that naproxen interacts with human COX-2 enzyme at a binding affinity of $-8.2 \mathrm{kcal} / \mathrm{mol}$ forming one hydrogen bond with TYR354.
\end{abstract}

Key words: Naproxen, Geometry, Polarizibility, Molecular docking.

\section{INTRODUCTION}

Non-steroidal anti-inflammatory drugs (NSAIDs) are an important class of compounds that exhibit a number of effects as a result of their ability to block cyclooxygenase (COX) enzyme. ${ }^{1}$ There are two isoforms of COX namely COX-1 and COX-2. The former is constitutively expressed in stomach, kidneys, and platelets and is considered important in mucosal protection and platelet function while the later one is inducible and plays a major role in prostaglandin biosynthesis in inflammatory cells. ${ }^{2}$

Naproxen (Figure 1) is a nonsteroidal antiinflammatory drug (NSAIDs) with analgesic, antipyretic and anti-inflammatory properties. It is a

Correspondence to: Mohammad A. Rashid

Tel.: +88-02-9661900-73, Extn.- 8137;

Fax: +88-02-9667222; E-mail: rashidma@du.ac.bd

Dhaka Univ. J. Pharm. Sci. 15(1): 37-45, 2016 (June) non-selective COX-2 inhibitor. The desired pharmacological activities of naproxen are obtained as a consequence of the inhibition of $\mathrm{COX}-2$; on the other hand, inhibition of $\mathrm{COX}-1$ leads to unwanted effects on the gastrointestinal tract such as ulceration, bleeding and perforation of gastrointestinal trac. ${ }^{1}$ To reduce this unwanted effects attempts were made to synthesize less toxic naproxen derivatives. ${ }^{3}$

A few computational and theoretical studies on naproxen were reported earlier. The vibrational and theoretical studies of naproxen were investigated by Jubert et al. ${ }^{4}$ Okulik and Jubert reported the theoretical study on the structure and reactive sites of naproxen. ${ }^{5}$ Musa and Eriksson, investigated the theoretical study of naproxen phototoxicity. ${ }^{6}$ Moreover, recently Khan and Rashid ${ }^{7}$ conducted a theoretical study of medium effects on solvation free energy, dipole moment and molecular reactivity of naproxen. ${ }^{7}$ 
Density Functional Theory (DFT) calculations provide a greater detail of molecular characteristics and interactions which lead to good understanding of molecular properties. $^{8}$ Consequently, the results would be potentially helpful for the development of pharmaceutical and (bio)chemical products. Hence, the present research have been undertaken to carry out computational assessment of geometry, molecular electrostatic potential (MESP), charge distribution, polarizability, hyperpolarizability using DFT and molecular docking study of naproxen with human COX-2 enzyme.
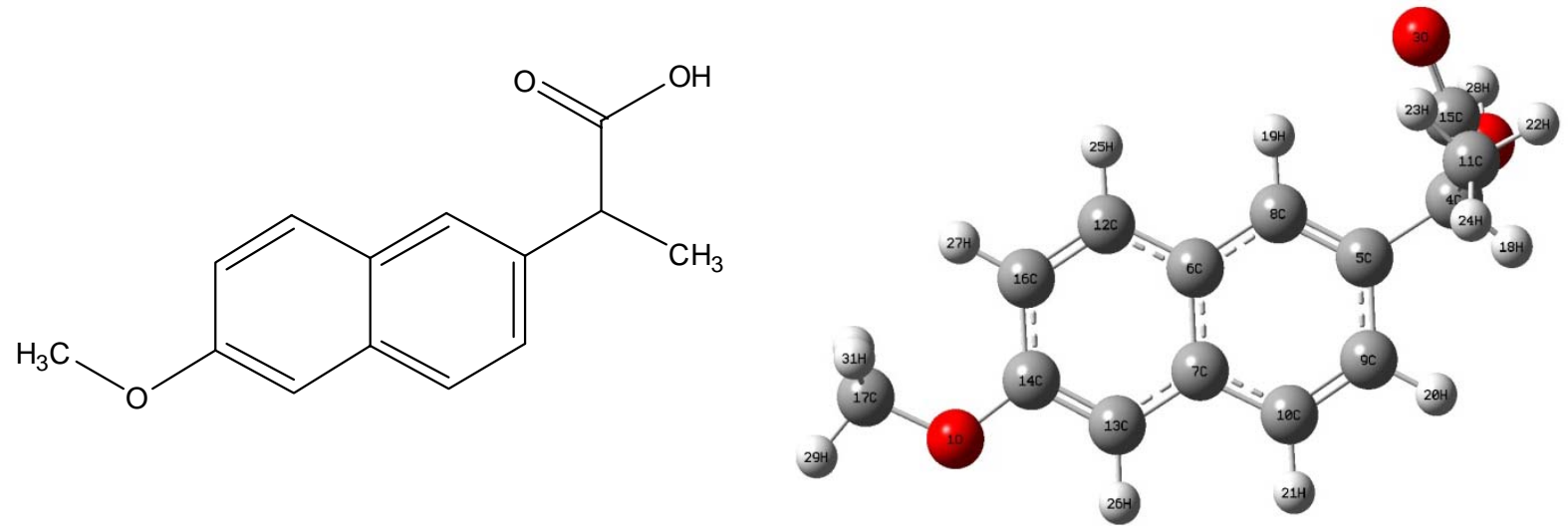

Figure 1. Structure of naproxen.

\section{METHODOLOGY}

Computational methods. All calculations were conducted with the Gaussian09 software package. ${ }^{9}$ The geometries of naproxen were optimized at the B3LYP level of theory with the 6-31G(d,p) basis set. Frequencies were calculated to ensure that the molecule is in the lowest energy state. The Polarizable Continuum Model (PCM) which is default in Gaussian 09 was used for all calculations involving the solvents, water and $n$-octanol. For Mulliken population analysis 6-31G(d) along with 6$31 \mathrm{G}(\mathrm{d}, \mathrm{p})$ basis sets were employed. All calculations involving solvation were performed using the optimized solution-phase structures.

\section{Molecular docking study}

Preparation of target protein X-ray structure. The crystal structure of human COX-2 in complex with celecoxib (PDB code: $3 \mathrm{LN} 1)^{10}$ was used as the protein target model in this docking study. Water molecules, ligands and chain B, C and D were removed and then polar hydrogen atoms were added to the proteins using PyMOL (Version 1.7.4.4,
Schrödinger). The amino acid sequence was started from 1 in the protein structure. Energy minimization was performed by applying YASARA force field level of theory in YASARA Energy Minimization Server (http://www.yasara.org/ minimizationserver.htm).

Preparation of ligands. The initial structure of the celecoxib (CID 2662) and naproxen (CID 156391) were obtained from pubchem (https:// pubchem.ncbi.nlm.nih.gov/search/). Molecular geometry optimization was then performed with the density functional theory (DFT) at the B3LYP/6$31 \mathrm{G}(\mathrm{d}, \mathrm{p})$ level using Gaussian 09 program. ${ }^{9}$ The optimized structures of ligands were then saved in PDB format for docking study.

Protein-ligand docking. The docking of the target protein with the ligand was performed using AutoDock vina ${ }^{11}$ in PyRx 0.8. Docking was carried out to obtain a population of possible conformations and orientations for the ligand at the binding site. Using PyRx 0.8 software, the macromolecule (COX2) and ligands were prepared and then docking was performed using a grid whose center was (34.8544, - 
$29.0810,-9.1090)$ and dimension was $(25.00,25.00$, 25.00) Angstrom ( $\AA$ ). Throughout the docking study the macromolecule was kept as rigid and ligand molecules were flexible. The best conformation was chosen with the lowest docked energy or binding affinity pose and ability to make bonding with the protein structure, after the docking search was completed. The interactions of complex proteinligand conformations, including hydrogen bonds and the bond lengths were analyzed using PyMOL (Figure 2).

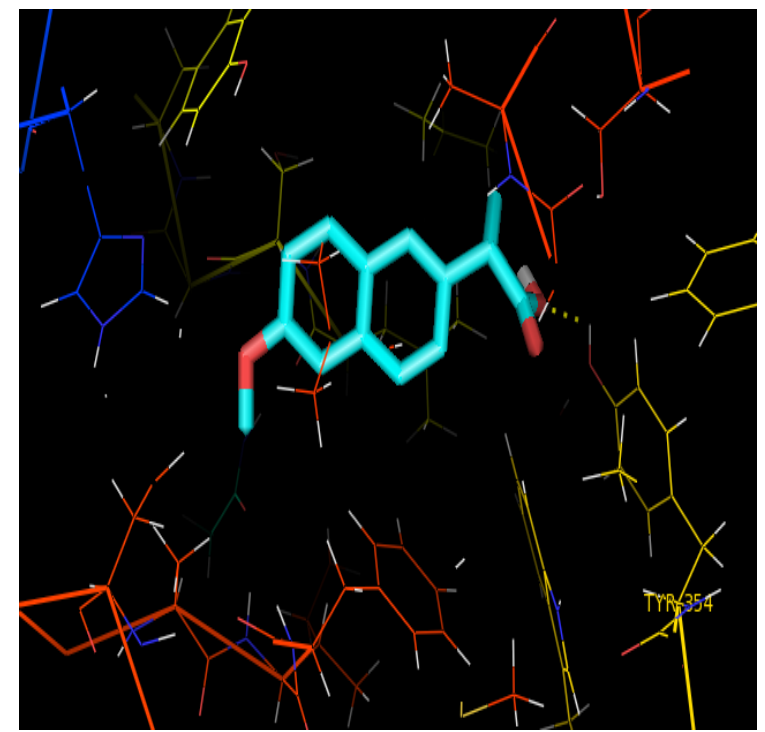

Figure 2. Binding mode of naproxen with cyclooxygenase-2 (3LN1) enzyme, visualized in PyMOL.

Before screening the ligands, the docking protocol was validated by redocking celecoxib and into the binding pocket of $3 \mathrm{LN} 1$ to obtain the docked pose and RMSD. The result showed that the first pose of celecoxib almost exactly superimpose with the experimental crystal structure of celecoxib (Figure 3). Thus, the protocol is good in reproducing the X-ray crystal structure and can be applied for further docking experiments.

\section{RESULTS AND DISCUSSION}

Equilibrium geometries. The optimized geometrical parameters such as bond lengths, bond angles and dihedral angles of naproxen obtained by the B3LYP/6-31G(d,p) are listed in Tables 1, 2 and 3 . The computed bond distances and bond angles were also compared with the X-ray crystallographic data. ${ }^{12}$ From the tables, it has been found that the calculated bond distances and bond angles agreed well with the experimental data, except for the $\mathrm{C}(4)-\mathrm{C}(15), \mathrm{C}(5)-\mathrm{C}(9), \mathrm{C}(16)-\mathrm{C}(14)$ and $\mathrm{O}(1)-\mathrm{C}(17)$ bond lengths and the $\mathrm{C}(5)-\mathrm{C}(4)-$ $\mathrm{C}(15), \mathrm{C}(8)-\mathrm{C}(6)-\mathrm{C}(7)$ and $\mathrm{C}(13)=\mathrm{C}(14)-\mathrm{O}(1)$ bond angle. The differences between the computed and experimental data are expressed as Mean Absolute Deviation (MAD) with the MAD of bond distances and bond angles of $0.017 \AA$ and $1.2^{\circ}$, respectively. However, comparison between the calculated and experimental dihedral angles was not possible due to lack of experimental value.

Molecular electrostatic potential (MESP). The molecular electrostatic potential (MESP) represents the net electrostatic effect of a molecule which is generated from the total charge distribution in the molecule. The MESP correlates very well with the partial charges, electronegativity and chemical reactivity of the molecule. ${ }^{13-15}$ In case of chemical reactivity, the region of the molecule susceptible to electrophilic or nucleophilic attack can be identified by the total electron density 


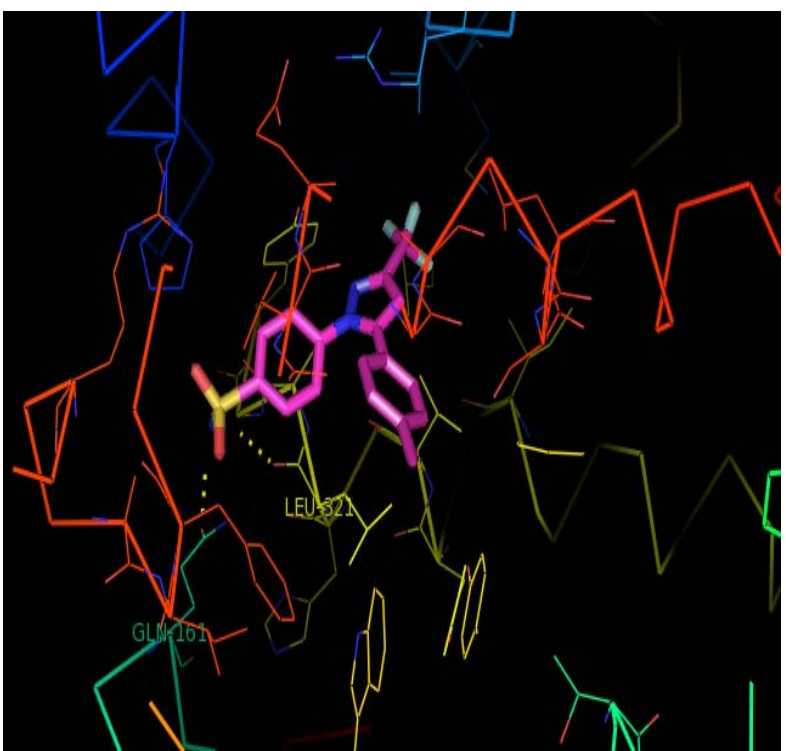

Interaction of experimental celecoxib with human COX-2 (3LN1) enzyme.

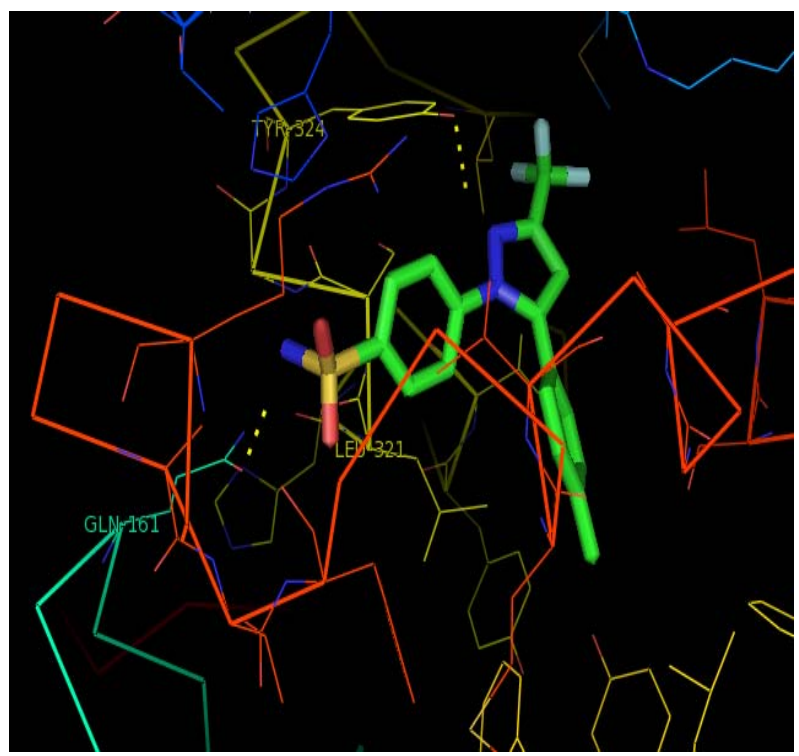

Interaction of best docked celecoxib with human $\mathrm{COX}-2$ (3LN1) enzyme.

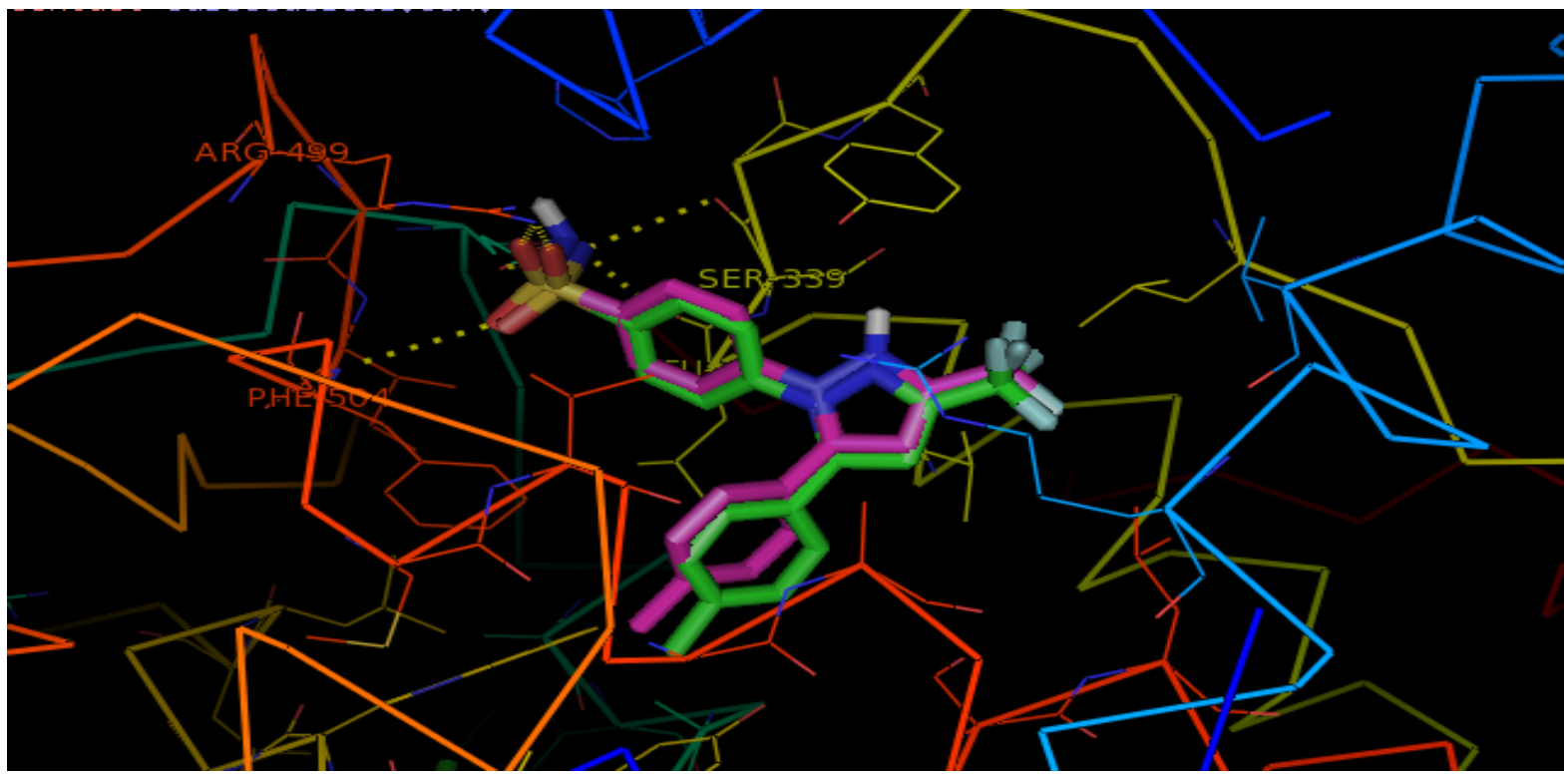

The superimposition of the best docking structure of celecoxib with the X-ray structure.

( $\square$ ) Experimental ligand, $(\square$ ) Docked ligand.

Figure 3. Best docked and experimental celecoxib with human COX-2 enzyme.

surface mapped with the electrostatic potential. The MESP contour map of naproxen calculated at the B3LYP/6-31G(d,p) is shown in figure 4 . In GaussView following 1 color scheme with the increasing order of potential is used: red $<$ orange $<$ yellow $<$ green $<$ cyan $<$ blue. The red (negative) and blue (positive) color regions in the MESP surface represent the regions susceptible to the attack of 
electrophiles and nucleophiles, respectively. However, the green indicates a region with zero electrostatic potential. The map reveals that the most possible sites for nucleophilic attack are $\mathrm{C} 15$ and $\mathrm{H} 28$ and electrophilic attack are $\mathrm{O} 1, \mathrm{O} 2, \mathrm{O} 3$ and $\mathrm{C} 11$.

Table 1. Theoretical (gas phase) and experimental (Xray diffraction) bond distances $(\AA)$ of naproxen calculated at B3LYP/6-31G(d,p).

\begin{tabular}{|c|c|c|}
\hline Assignment & $\begin{array}{c}\text { Bond distance } \\
(\AA)\end{array}$ & Experimental $^{12}$ \\
\hline $\mathrm{C}(11)-\mathrm{H}(22)$ & 1.095 & - \\
\hline $\mathrm{C}(11)-\mathrm{H}(23)$ & 1.092 & - \\
\hline $\mathrm{C}(11)-\mathrm{H}(24)$ & 1.093 & - \\
\hline$C(11)-C(4)$ & 1.538 & 1.556 \\
\hline $\mathrm{C}(4)-\mathrm{H}(18)$ & 1.094 & - \\
\hline$C(4)-C(15)$ & 1.522 & 1.501 \\
\hline $\mathrm{C}(15)=\mathrm{O}(3)$ & 1.213 & 1.225 \\
\hline $\mathrm{C}(15)-\mathrm{O}(2)$ & 1.354 & 1.345 \\
\hline $\mathrm{O}(2)-\mathrm{H}(28)$ & 0.973 & - \\
\hline$C(4)-C(5)$ & 1.529 & 1.523 \\
\hline$C(5)=C(8)$ & 1.38 & 1.36 \\
\hline $\mathrm{C}(8)-\mathrm{H}(19)$ & 1.087 & - \\
\hline$C(5)-C(9)$ & 1.422 & 1.388 \\
\hline $\mathrm{C}(9)-\mathrm{H}(20)$ & 1.087 & - \\
\hline$C(9)=C(10)$ & 1.374 & 1.37 \\
\hline $\mathrm{C}(10)-\mathrm{H}(21)$ & 1.087 & - \\
\hline$C(10)-C(7)$ & 1.423 & 1.406 \\
\hline$C(7)-C(6)$ & 1.434 & 1.419 \\
\hline$C(6)-C(8)$ & 1.42 & 1.412 \\
\hline$C(6)-C(12)$ & 1.417 & 1.408 \\
\hline $\mathrm{C}(12)-\mathrm{H}(25)$ & 1.087 & - \\
\hline$C(12)=C(16)$ & 1.378 & 1.358 \\
\hline $\mathrm{C}(16)-\mathrm{H}(27)$ & 1.083 & - \\
\hline$C(16)-C(14)$ & 1.42 & 1.448 \\
\hline$C(14)=C(13)$ & 1.383 & 1.366 \\
\hline$C(13)-C(7)$ & 1.413 & 1.431 \\
\hline $\mathrm{C}(13)-\mathrm{H}(26)$ & 1.086 & - \\
\hline $\mathrm{C}(14)-\mathrm{O}(1)$ & 1.367 & 1.358 \\
\hline $\mathrm{O}(1)-\mathrm{C}(17)$ & 1.419 & 1.454 \\
\hline $\mathrm{C}(17)-\mathrm{H}(29)$ & 1.091 & - \\
\hline $\mathrm{C}(17)-\mathrm{H}(30)$ & 1.098 & - \\
\hline $\mathrm{C}(17)-\mathrm{H}(31)$ & 1.098 & - \\
\hline MAD & 0.017 & \\
\hline
\end{tabular}

Table 2. Theoretical (gas phase) and experimental (Xray diffraction) bond angle ( ) and dihedral angles ( ) of naproxen calculated at B3LYP/6-31G(d,p).

\begin{tabular}{|c|c|c|}
\hline Assignment & Bond angle( ) & Experimental $^{12}$ \\
\hline $\mathrm{H}(22)-\mathrm{C}(11)-\mathrm{H}(24)$ & 108.5 & - \\
\hline $\mathrm{H}(22)-\mathrm{C}(11)-\mathrm{H}(23)$ & 108.0 & - \\
\hline $\mathrm{H}(23)-\mathrm{C}(11)-\mathrm{C}(4)$ & 110.4 & - \\
\hline $\mathrm{H}(24)-\mathrm{C}(11)-\mathrm{C}(4)$ & 110 & - \\
\hline $\mathrm{C}(11)-\mathrm{C}(4)-\mathrm{H}(18)$ & 109.6 & - \\
\hline$C(11)-C(4)-C(15)$ & 110.5 & - \\
\hline $\mathrm{C}(4)-\mathrm{C}(15)-\mathrm{O}(2)$ & 112.0 & 113.8 \\
\hline $\mathrm{C}(4)-\mathrm{C}(15)=\mathrm{O}(3)$ & 125.6 & 125.4 \\
\hline $\mathrm{O}(2)-\mathrm{C}(15)=\mathrm{O}(3)$ & 122.4 & 120.7 \\
\hline $\mathrm{C}(15)-\mathrm{O}(2)-\mathrm{H}(28)$ & 106.1 & - \\
\hline$C(5)-C(4)-C(15)$ & 109.5 & 105.7 \\
\hline $\mathrm{C}(5)-\mathrm{C}(4)-\mathrm{H}(18)$ & 107.8 & - \\
\hline$C(5)=C(8)-C(6)$ & 121.4 & 123.4 \\
\hline $\mathrm{C}(8)-\mathrm{C}(6)-\mathrm{C}(7)$ & 119.4 & 123.3 \\
\hline$C(6)-C(7)-C(10)$ & 118.1 & 118.3 \\
\hline$C(7)-C(10)=C(9)$ & 120.9 & 120.8 \\
\hline$C(10)=C(9)-C(5)$ & 121.3 & 121.9 \\
\hline$C(4)-C(5)-C(9)$ & 119.7 & 119.7 \\
\hline$C(4)-C(5)=C(8)$ & 121.5 & 122.6 \\
\hline $\mathrm{C}(5)=\mathrm{C}(8)-\mathrm{H}(19)$ & 119.9 & - \\
\hline $\mathrm{C}(6)-\mathrm{C}(8)-\mathrm{H}(19)$ & 118.7 & - \\
\hline $\mathrm{C}(5)-\mathrm{C}(9)-\mathrm{H}(20)$ & 119.0 & - \\
\hline$C(10)=C(9)-H(20)$ & 119.7 & - \\
\hline $\mathrm{C}(9)=\mathrm{C}(10)-\mathrm{H}(21)$ & 120.2 & - \\
\hline $\mathrm{C}(7)-\mathrm{C}(10)-\mathrm{H}(21)$ & 118.9 & - \\
\hline$C(8)-C(6)-C(12)$ & 122.3 & 123.3 \\
\hline $\mathrm{C}(6)-\mathrm{C}(12)-\mathrm{H}(25)$ & 118.8 & - \\
\hline $\mathrm{C}(16)=\mathrm{C}(12)-\mathrm{H}(25)$ & 119.6 & - \\
\hline$C(12)=C(16)-C(14)$ & 119.9 & 120.1 \\
\hline$C(16)-C(14)=C(13)$ & 120 & 119.2 \\
\hline $\mathrm{C}(14)=\mathrm{C}(13)-\mathrm{C}(7)$ & 120.8 & 120.9 \\
\hline$C(13)-C(7)-C(6)$ & 119.4 & 119.1 \\
\hline$C(7)-C(6)-C(12)$ & 118.3 & 118.8 \\
\hline $\mathrm{C}(12)=\mathrm{C}(16)-\mathrm{H}(27)$ & 119.6 & - \\
\hline $\mathrm{C}(14)-\mathrm{C}(16)-\mathrm{H}(27)$ & 120.5 & - \\
\hline$C(14)=C(13)-H(26)$ & 118.8 & - \\
\hline $\mathrm{C}(7)-\mathrm{C}(13)-\mathrm{H}(26)$ & 120.3 & - \\
\hline$C(13)=C(14)-O(1)$ & 123.7 & 126.6 \\
\hline $\mathrm{C}(16)-\mathrm{C}(14)-\mathrm{O}(1)$ & 116.3 & 114.2 \\
\hline $\mathrm{C}(14)-\mathrm{O}(1)-\mathrm{C}(17)$ & 118.8 & 117.9 \\
\hline $\mathrm{O}(1)-\mathrm{C}(17)-\mathrm{H}(29)$ & 105.9 & - \\
\hline $\mathrm{O}(1)-\mathrm{C}(17)-\mathrm{H}(30)$ & 111.9 & - \\
\hline $\mathrm{O}(1)-\mathrm{C}(17)-\mathrm{H}(31)$ & 111.9 & - \\
\hline $\mathrm{H}(29)-\mathrm{C}(17)-\mathrm{H}(30)$ & 109 & - \\
\hline $\mathrm{H}(29)-\mathrm{C}(17)-\mathrm{H}(31)$ & 109 & - \\
\hline $\mathrm{H}(30)-\mathrm{C}(17)-\mathrm{H}(31)$ & 109.1 & - \\
\hline MAD & 1.2 & - \\
\hline
\end{tabular}


Table 3. Theoretical (gas phase) and experimental (X-ray diffraction) dihedral angles ( ) of naproxen calculated at B3LYP/6-31G(d,p).

\begin{tabular}{|c|c|c|c|}
\hline Assignment & Dihedral angle & Assignment & Dihedral angle \\
\hline $\mathrm{C}(17)-\mathrm{O}(1)-\mathrm{C}(14)-\mathrm{C}(16)$ & 0 & $\mathrm{H}(24)-\mathrm{C}(11)-\mathrm{C}(4)-\mathrm{H}(18)$ & -64.2 \\
\hline$C(13)=C(14)-O(1)-C(17)$ & -179.9 & $\mathrm{H}(22)-\mathrm{C}(11)-\mathrm{C}(4)-\mathrm{C}(15)$ & -61.8 \\
\hline $\mathrm{O}(1)-\mathrm{C}(14)-\mathrm{C}(16)-\mathrm{C}(12)$ & -180 & $\mathrm{H}(23)-\mathrm{C}(11)-\mathrm{C}(4)-\mathrm{C}(15)$ & 58 \\
\hline $\mathrm{O}(1)-\mathrm{C}(14)=\mathrm{C}(13)-\mathrm{C}(7)$ & -180 & $\mathrm{H}(24)-\mathrm{C}(11)-\mathrm{C}(4)-\mathrm{C}(15)$ & 178.1 \\
\hline$C(14)-C(16)=C(12)-C(6)$ & 0 & $\mathrm{H}(18)-\mathrm{C}(4)-\mathrm{C}(15)=\mathrm{O}(3)$ & -153.8 \\
\hline $\mathrm{H}(4)-\mathrm{C}(1)-\mathrm{C}(5)-\mathrm{O}(7)$ & -59 & $\mathrm{H}(18)-\mathrm{C}(4)-\mathrm{C}(15)-\mathrm{O}(2)$ & 27.7 \\
\hline $\mathrm{C}(16)=\mathrm{C}(12)-\mathrm{C}(6)-\mathrm{C}(7)$ & 0.1 & $\mathrm{H}(28)-\mathrm{O}(2)-\mathrm{C}(15)=\mathrm{O}(3)$ & -1.6 \\
\hline $\mathrm{C}(12)-\mathrm{C}(6)-\mathrm{C}(7)-\mathrm{C}(13)$ & 0 & $\mathrm{H}(28)-\mathrm{O}(2)-\mathrm{C}(15)-\mathrm{C}(4)$ & 177.1 \\
\hline$C(6)-C(7)-C(13)=C(14)$ & 0 & $\mathrm{H}(19)-\mathrm{C}(8)=\mathrm{C}(5)-\mathrm{C}(4)$ & 2.5 \\
\hline$C(16)=C(12)-C(6)-C(8)$ & -180 & $\mathrm{H}(19)-\mathrm{C}(8)=\mathrm{C}(5)-\mathrm{C}(9)$ & -179.2 \\
\hline $\mathrm{C}(12)-\mathrm{C}(6)-\mathrm{C}(8)=\mathrm{C}(5)$ & -179.9 & $\mathrm{H}(19)-\mathrm{C}(8)-\mathrm{C}(6)-\mathrm{C}(12)$ & -0.5 \\
\hline $\mathrm{C}(6)-\mathrm{C}(8)=\mathrm{C}(5)-\mathrm{C}(9)$ & 0.2 & $\mathrm{H}(20)-\mathrm{C}(9)-\mathrm{C}(5)-\mathrm{C}(4)$ & -2 \\
\hline$C(8)=C(5)-C(9)=C(10)$ & -0.3 & $\mathrm{H}(20)-\mathrm{C}(9)-\mathrm{C}(5)-\mathrm{C}(8)$ & 179.7 \\
\hline$C(5)-C(9)=C(10)-C(7)$ & 0.2 & $\mathrm{H}(20)-\mathrm{C}(9)=\mathrm{C}(10)-\mathrm{H}(21)$ & 0 \\
\hline$C(9)=C(10)-C(7)-C(6)$ & 0 & $\mathrm{H}(20)-\mathrm{C}(9)=\mathrm{C}(10)-\mathrm{C}(7)$ & -179.8 \\
\hline $\mathrm{C}(10)-\mathrm{C}(7)-\mathrm{C}(6)-\mathrm{C}(8)$ & -0.1 & $\mathrm{H}(21)-\mathrm{C}(10)-\mathrm{C}(9)-\mathrm{C}(5)$ & -180 \\
\hline $\mathrm{C}(13)-\mathrm{C}(7)-\mathrm{C}(10)=\mathrm{C}(9)$ & 179.9 & $\mathrm{H}(21)-\mathrm{C}(10)-\mathrm{C}(7)-\mathrm{C}(13)$ & 0.1 \\
\hline $\mathrm{C}(6)-\mathrm{C}(8)=\mathrm{C}(5)-\mathrm{C}(4)$ & -178.1 & $\mathrm{H}(26)-\mathrm{C}(13)-\mathrm{C}(7)-\mathrm{C}(10)$ & 0.1 \\
\hline$C(10)=C(9)-C(5)-C(4)$ & 178 & $H(26)-C(13)=C(14)-C(16)$ & -180 \\
\hline$C(8)=C(5)-C(4)-C(15)$ & -51.4 & $\mathrm{H}(26)-\mathrm{C}(13)=\mathrm{C}(14)-\mathrm{O}(1)$ & 0 \\
\hline C(9)-C(5)-C(4)-C(15) & 130.3 & $\mathrm{H}(29)-\mathrm{C}(17)-\mathrm{O}(1)-\mathrm{C}(14)$ & 179.9 \\
\hline $\mathrm{C}(5)-\mathrm{C}(4)-\mathrm{C}(15)-\mathrm{O}(2)$ & -89 & $\mathrm{H}(30)-\mathrm{C}(17)-\mathrm{O}(1)-\mathrm{C}(14)$ & 61.3 \\
\hline$C(5)-C(4)-C(15)=O(3)$ & 89.6 & $\mathrm{H}(31)-\mathrm{C}(17)-\mathrm{O}(1)-\mathrm{C}(14)$ & -61.4 \\
\hline $\mathrm{C}(11)-\mathrm{C}(4)-\mathrm{C}(15)=\mathrm{O}(3)$ & -34.5 & $\mathrm{H}(27)-\mathrm{C}(16)-\mathrm{C}(14)=\mathrm{C}(13)$ & 180 \\
\hline C(9)-C(5)-C(4)-C(11) & -106.6 & $\mathrm{H}(27)-\mathrm{C}(16)=\mathrm{C}(12)-\mathrm{C}(6)$ & 180 \\
\hline$C(8)-C(5)-C(4)-C(11)$ & 71.6 & $\mathrm{H}(27)-\mathrm{C}(16)=\mathrm{C}(12)-\mathrm{H}(25)$ & 0 \\
\hline $\mathrm{H}(22)-\mathrm{C}(11)-\mathrm{C}(4)-\mathrm{H}(18)$ & 56 & $\mathrm{H}(25)-\mathrm{C}(12)=\mathrm{C}(16)-\mathrm{C}(14)$ & 180 \\
\hline \multirow[t]{2}{*}{$\mathrm{H}(23)-\mathrm{C}(11)-\mathrm{C}(4)-\mathrm{H}(18)$} & 175.8 & $\mathrm{H}(25)-\mathrm{C}(12)-\mathrm{C}(6)-\mathrm{C}(8)$ & 0 \\
\hline & & $\mathrm{H}(25)-\mathrm{C}(12)-\mathrm{C}(6)-\mathrm{C}(7)$ & -179.9 \\
\hline
\end{tabular}

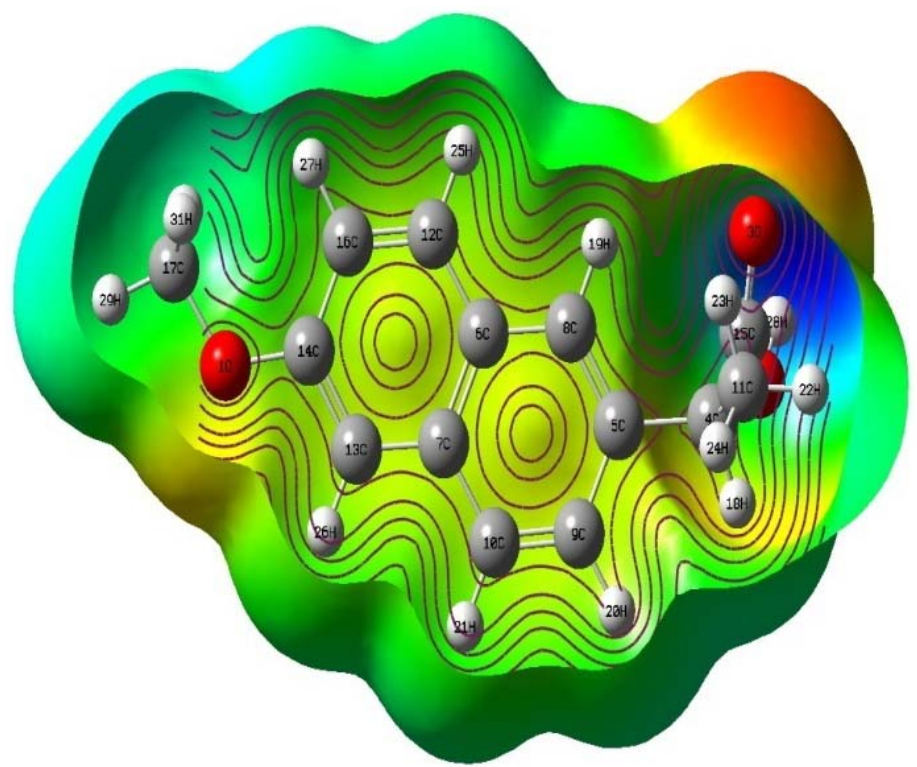

Figure 4. Electrostatic potential contour of naproxen. 
Mulliken and Natural population analysis. The Mulliken population Analysis (MPA) shows the simplest picture of charge distribution. The Mulliken charges present net atomic charges in the molecule while electrostatic potentials are generated by the electric field of internal charge distribution. Thus, in the reactivity studies, population analysis (MPA) and MESP are complementary tools, and correlation between the schemes is expected. ${ }^{16}$ In this study, MPA was conducted to understand the charge distribution in the atoms of naproxen. The Mulliken charge distribution of naproxen was calculated using
B3LYP level of theory with 6-31G(d) and 6-31G(d,p) basis sets. According to MPA, among all the carbon atoms the $\mathrm{C} 15$ has the highest negative charge (Table 4). The presence of two oxygen atoms $\mathrm{O} 2$ and $\mathrm{O} 3$ imposes large positive charges on $\mathrm{C} 15$ atom. The MPA shows that all the hydrogen and oxygen atoms have positive and negative charges, respectively. Among all the $\mathrm{H}$ atoms, the $\mathrm{H} 28$ possesses highest positive charge. This shows that the charge distribution and the MESP information are concordant.

Table 4. Atomic charges of naproxen obtained from Mulliken population analysis (MPA).

\begin{tabular}{|c|c|c|c|c|c|}
\hline \multirow[t]{2}{*}{ Atom } & \multicolumn{2}{|c|}{ B3LYP } & \multirow[t]{2}{*}{ Atom } & \multicolumn{2}{|c|}{ B3LYP } \\
\hline & $6-31 G(d)$ & $6-31 G(d, p)$ & & $6-31 G(d)$ & $6-31 G(d, p)$ \\
\hline $\mathrm{O} 1$ & -0.510 & -0.521 & H18 & 0.157 & 0.114 \\
\hline $\mathrm{O} 2$ & -0.570 & -0.489 & H19 & 0.153 & 0.106 \\
\hline $\mathrm{O} 3$ & -0.471 & -0.473 & $\mathrm{H} 20$ & 0.126 & 0.081 \\
\hline $\mathrm{C} 4$ & -0.235 & -0.184 & $\mathrm{H} 21$ & 0.131 & 0.085 \\
\hline $\mathrm{C} 5$ & 0.147 & 0.101 & $\mathrm{H} 22$ & 0.150 & 0.108 \\
\hline C6 & 0.145 & 0.105 & $\mathrm{H} 23$ & 0.173 & 0.132 \\
\hline $\mathrm{C} 7$ & 0.148 & 0.110 & $\mathrm{H} 24$ & 0.152 & 0.108 \\
\hline $\mathrm{C} 8$ & -0.261 & -0.172 & $\mathrm{H} 25$ & 0.137 & 0.091 \\
\hline $\mathrm{C} 9$ & -0.189 & -0.128 & $\mathrm{H} 26$ & 0.135 & 0.091 \\
\hline $\mathrm{C} 10$ & -0.194 & -0.133 & $\mathrm{H} 27$ & 0.134 & 0.088 \\
\hline $\mathrm{C} 11$ & -0.435 & -0.297 & $\mathrm{H} 28$ & 0.407 & 0.320 \\
\hline $\mathrm{C} 12$ & -0.202 & -0.143 & $\mathrm{H} 29$ & 0.171 & 0.126 \\
\hline $\mathrm{C} 13$ & -0.263 & -0.180 & H30 & 0.152 & 0.112 \\
\hline C14 & 0.382 & 0.351 & H31 & 0.152 & 0.112 \\
\hline $\mathrm{C} 15$ & 0.591 & 0.591 & & & \\
\hline $\mathrm{C} 16$ & -0.195 & -0.132 & & & \\
\hline $\mathrm{C} 17$ & -0.215 & -0.078 & & & \\
\hline
\end{tabular}

Polarizability and first order hyperpolarizability. Polarizability is the measure of distortion of a molecule in an electric field. It is a tensor and can be represented in a $3 \times 3$ real symmetric matrix i.e. the off-diagonal elements are equal. The polarizability $(\alpha)$ was calculated using the following equation:

$$
\alpha=\frac{1}{3}\left(\alpha_{x x}+\alpha_{y y}+\alpha_{z z}\right)
$$

The quantities $\alpha_{\mathrm{xx}}, \alpha_{\mathrm{yy}}$ and $\alpha_{\mathrm{zz}}$ are known as principal values of polarizability tensor.

This property measures the strength of molecular interactions (e.g., long-range intermolecular induction, dispersion forces, etc.), the cross sections of different scattering and collision processes, and the optical properties of a system. ${ }^{17}$ The calculated polarizability of naproxen in gas phase and different solvents namely water and $n$-octanol is presented in 
Table 5. The polarizability $\left(\alpha_{t o t}\right)$ of naproxen was $163.37,216.70$ and 208.13 a.u. in gas phase, water and $n$-octanol respectively. It is clear from the Table 5 that the polarizability gradually increases when going from lower to higher dielectric constant i.e. the reactivity increases with increasing the polarity of the solvent.

The first order hyperpolarizability $(\beta)$ is the measure of the nonlinear optical activity which can be of different types such as $\beta_{\mathrm{vec}}$ ( $\beta$ vector), $\beta_{\|}(\beta$ parallel) and $\beta_{\text {tot }}(\beta$ total $)$. It is a third rank tensor that can be described by a $3 \times 3 \times 3$ matrix. The Kleinman symmetry enables to reduce the 27 components of $3 \mathrm{D}$ matrix into 10 components. ${ }^{18}$ GAUSSIAN provides 10 components of this matrix as $\beta_{\mathrm{xxx}}, \beta_{\mathrm{yxx}}, \beta_{\mathrm{xyy}}, \beta_{\mathrm{yyy}}$, $\beta_{\mathrm{xxz}}, \beta_{\mathrm{xyz}}, \beta_{\mathrm{yyz}}, \beta_{\mathrm{xxz}}, \beta_{\mathrm{yzz}}, \beta_{\mathrm{zzz}}$, respectively, from which all $x, y$ and $z$ components of $\beta$ can be calculated. The hyperpolarizability $\left(\beta_{t o t}\right)$ can be calculated using the following equation:

$$
\begin{aligned}
& \beta_{\text {tot }}=\left(\beta_{x}^{2}+\beta_{y}^{2}+\beta_{z}^{2}\right)^{1 / 2} \\
& \text { Where, } \\
& \qquad \beta_{\mathrm{x}}=\beta_{\mathrm{xxx}}+\beta_{\mathrm{xyy}}+\beta_{\mathrm{xzz}} \\
& \beta_{\mathrm{y}}=\beta_{\mathrm{yyy}}+\beta_{\mathrm{xxy}}+\beta_{\mathrm{yzz}} \\
& \beta_{\mathrm{z}}=\beta_{\mathrm{zzz}}+\beta_{\mathrm{xxz}}+\beta_{\mathrm{yyz}}
\end{aligned}
$$

The $\beta_{\text {tot }}$ for different solvents is listed in Table 5, which shows that the hyperpolarizability in gas phase, water and n-octanol was 73.07, 91.79 and 89.14 a.u., respectively. However, the hyperpolarizability also increases on going from lower to higher dielectric constant i.e. from non-polar to polar solvents.

Table 5. Effect of solvent polarity on polarizability (a.u.) and first order hyperpolarizability (a,u.) calculated at B3LYP/6-31G(d,p).

\begin{tabular}{lcccccccc}
\hline $\begin{array}{l}\text { Medium (dielectric } \\
\text { constant) }\end{array}$ & $\alpha_{\mathrm{xx}}$ & $\alpha_{\mathrm{yy}}$ & $\alpha_{\mathrm{zz}}$ & $\alpha_{\text {tot }}$ & $\beta_{\mathrm{x}}$ & $\beta_{\mathrm{y}}$ & $\beta_{\mathrm{z}}$ & $\beta_{\text {tot }}$ \\
\hline Gas Phase & 249.77 & 153.57 & 86.77 & 163.37 & 47.49 & -33.56 & -44.25 & 73.07 \\
Water (78.3) & 322.42 & 219.19 & 108.47 & 216.70 & 71.98 & -26.75 & -50.29 & 91.79 \\
n-Octanol (9.9) & 312.21 & 207.50 & 104.68 & 208.13 & 67.71 & -30.30 & -49.43 & 89.14 \\
\hline
\end{tabular}

Table 6. The binding affinity (Kcal/mol) of celecoxib and naproxen with cyclooxygenase-2 (3LN1) enzyme.

\begin{tabular}{ccccc}
\hline Compound name & $\begin{array}{c}\text { Binding affinity } \\
(\mathrm{Kcal} / \mathrm{mol})\end{array}$ & Molecular formula & $\begin{array}{c}\text { Molecular } \\
\text { weight }\end{array}$ & $\begin{array}{c}\text { Interacting residues in } \\
\text { PyMOL }\end{array}$ \\
\hline Celecoxib & -11.3 & $\mathrm{C}_{17} \mathrm{H}_{14} \mathrm{~F}_{3} \mathrm{~N}_{3} \mathrm{O}_{2} \mathrm{~S}$ & 381.08 & $\begin{array}{c}\text { GLN161, LEU321, } \\
\text { TYR324 }\end{array}$ \\
Naproxen & -8.2 & $\mathrm{C}_{14} \mathrm{H}_{14} \mathrm{O}_{3}$ & 230.3 & TYR354 \\
\hline
\end{tabular}

Molecular docking study. Molecular docking study of naproxen was carried out with human COX2 enzyme using AutoDock Vina, to identify and understand the binding mode of naproxen and the intermolecular hydrogen bond interaction between with the target protein. From our docking study it was found that naproxen interacts with $\mathrm{COX}-2$ at a binding affinity of $-8.2 \mathrm{kcal} / \mathrm{mol}$ whereas for celecoxib it was $-11.3 \mathrm{Kcal} / \mathrm{mol}$. Moreover, naproxen forms one hydrogen bond with TYR354 of COX-2 enzyme. The docking result of naproxen with human COX-2 (3LN1) is presented in Table 6.

\section{CONCLUSIONS}

The geometry, molecular electrostatic potential (MESP), Mulliken charge distribution, polarizability, hyperpolarizability and molecular docking studies of naproxen with human COX-2 enzyme were conducted. Almost all bond lengths and angles of the naproxen agree very well with the X-ray crystal structure suggesting that the molecule is well described with B3LYP/6-31G(d,p) level of theory. The polarizability and first order hyperpolarizability increase with the increase of solvent polarity. Moreover, docking study revealed that naproxen 
interacts with human COX-2 enzyme at a binding affinity of $-8.2 \mathrm{kcal} / \mathrm{mol}$ forming one hydrogen bond with TYR354.

\section{REFERENCES}

1. Insel, P.A. 1996. Analgesic-antipyretic and anti-inflammatory agents and drugs employed in the treatment of gout. In: The Pharmacological Basis of Therapeutics, 9th ed.; Hardman, J. G., Limbird, L. E., Molinoff, P. B., Ruddon, R. W. and Gilman, A. G. Eds. McGraw-Hill: New York, pp. 617-657.

2. Griswold, D.E. and Adams, L. 1996. Constitutive cyclooxygenase (cox-1) and inducible cyclooxygenase (COX2): Rationale for selective inhibition and progress to date. Med. Res. Rev. 16, 181-206.

3. Akter, M., Saha, S.K. and Rahman, S.M.A. 2015. Gastroenterohistopathology studies of synthesized naproxen esters in young healthy Sprague-Dawley rat model. Dhaka Univ. J. Pharm. Sci. 14, 49-53.

4. Jubert, A., Legarto, M.L., Massa, N.E., Tevez, L.L. and Okulik, N.B. 2006. Vibrational and theoretical studies of nonsteroidal anti-inflammatory drugs Ibuprofen [2-(4isobutylphenyl)propionic acid]; Naproxen [6-methoxy-amethyl-2-naphthalene acetic acid] and Tolmetin acids [1methyl-5-(4-methylbenzoyl)-1H-pyrrole-2-acetic acid]. $J$. Mol. Struct. 783, 34-51.

5. Okulik N. and Jubert A.H. 2006. Theoretical study on the structure and reactive sites of three non-steroidal antiinflammatory drugs: Ibuprofen, Naproxen and Tolmetin acids. J. Mol. Struct.:THEOCHEM. 769, 135-141.

6. Musa K.A.K. and Eriksson L.A. 2008. Theoretical study of the phototoxicity of naproxen and the active form of nabumetone. J. Phys. Chem. A. 112, 10921-10930.

7. Khan, M.F. and Rashid. R.B. 2015. Medium effect on solvation free energy, dipole moment and molecular reactivity of naproxen. J. Theor. Comput. Sci. 2, 01-04.

8. Jayaprakash, A., Arjunan, V., Jose, S.P. and Mohan, S. Vibrational and electronic investigations, thermodynamic parameters, HOMO and LUMO analysis on crotonaldehyde by ab initio and DFT methods. Spectrochimica Acta Part A. 20100, 83, 411- 419 .

9. Frisch, M.J., Trucks, G.W., Schlegel, H.B., Scuseria, G.E., Robb, M.A., Cheeseman, J.R., Scalmani, G., Barone, V., Mennucci, B.G., Petersson, A., Nakatsuji, H., Caricato, M., Li, X., Hratchian, H.P., Izmaylov, A.F., Bloino, J., Zheng, G., Sonnenberg, J.L., Hada, M., Ehara, Toyota, M.K., Fukuda, R., Hasegawa, J., Ishida, M., Nakajima, T., Honda, Y., Kitao, O., Nakai, H., Vreven, T., Montgomery Jr., J.A., Peralta, J.E., Ogliaro, F., Bearpark, M., Heyd, J.J., Brothers, E., Kudin,
K.N., Staroverov, V.N., Kobayashi, R., Normand, J., Raghavachari, Rendell, K.A., Burant, J.C., Iyengar, S.S., Tomasi, J., Cossi, M., Rega, N., Millam, J.M., Klene, M., Knox, J.E., Cross, J.B., Bakken, V., Adamo, C., Jaramillo, J., Gomperts, R., Stratmann, R.E., Yazyev, O., Austin, A.J., Cammi, R., Pomelli, C., Ochterski, J.W., Martin, R.L., Morokuma, K., Zakrzewski, V.G., Voth, G.A., Salvador, P., Dannenberg,J.J., Dapprich, S., Daniels, A.D., Farkas,O., Foresman, J.B., Ortiz, J.V., Cioslowski, J. and Fox, D.J. 2009. Gaussian 09, Revision A.02, Gaussian, Inc., Wallingford, CT.

10. Wang, J.L., Limburg, D., Graneto, M.J., Springer, J., Hamper, J.R., Liao, S., Pawlitz, J.L., Kurumbail, R.G., Maziasz. T., Talley, J.J., Kiefer, J.R. and Carter, J.. 2010. The novel benzopyran class of selective cyclooxygenase-2 inhibitors. Part 2: the second clinical candidate having a shorter and favorable human half-life. Bioorg. Med. Chem. Lett. 20, 7159-7163.

11. Trott, O. and Olson, A.J. 2010. Software news and update AutoDock Vina: improving the speed and accuracy of docking with a new scoring function, efficient optimization, and multithreading. J. Comput. Chem. 31, 455-46.

12. Ravikumar, K., Rajan, S.S. and Pattabhi, V. 1985. Structure of naproxen, $\mathrm{C}_{14} \mathrm{H}_{14} \mathrm{O}_{3}$. J. Acta Cryst. C41, 280-282.

13. Suhasini, M., Sailatha, E., Gunasekaran, S. and Ramkuma, G.R. 2015. Vibrational and electronic investigations, thermodynamic parameters, HOMO and LUMO analysis on lornoxicam by density functional theory. J. Mol. Struct. 1100, 116-128.

14. Govindarajan, M., Karabacak, M., Periandy, S. and Xavier, S. 2012. Vibrational spectroscopic studies, NLO, HOMOLUMO and electronic structure calculations of $\alpha, \alpha, \alpha-$ trichlorotoluene using HF and DFT. Spectrochimica Acta Part A: Mol. Biomol. Spectros. 94, 53-64.

15. Munoz-Caro, C., Niño, A., Senent, M.L., Leal, J.M. and Ibeas, S. 2000. Modeling of protonation processes in acetohydroxamic acid. J. Org. Chem. 65, 405-410.

16. Santamaria, R., Cocho, G., Corona, L. and González, E. 1998. Molecular electrostatic potentials and Mulliken charge populations of DNA mini-sequences. Chemical Physics. 227, 317-329.

17. Targema, M., Obi-Egbedi, N.O. and Adeoye, M.D. 2013. Molecular structure and solvent effects on the dipole moments and polarizabilities of some aniline derivatives. Comput. Theor. Chem. 1012, 47-53.

18. Kleinman, D.A. 1962. Nonlinear dielectric polarization in optical media. Phys. Rev. 126, 1977. 